\title{
Magic as a Political Crime in Medieval and Early Modern England: A History of Sorcery and Treason
}

\author{
Review Number: 2219 \\ Publish date: Thursday, 1 February, 2018 \\ Author: Francis Young \\ ISBN: 9781788310215
}

Date of Publication: 2017

Price: $£ 69.00$

Pages: 272pp.

Publisher: I. B. Tauris

Publisher url: http://ibtauris.com/Books/Humanities/Religion--beliefs/Alternative-belief-systems/Occult-studies/Ma alchemy--hermetic-thought/Magic-as-a-Political-Crime-in-Medieval-and-Early-Modern-England-A-H of-Sorcery-and-Treason?menuitem=\%7B1D4E2176-5DB1-4A0F-91EF-D6445C14D58E\%7D

Place of Publication: London

Reviewer: Coral Casey-Stoakes

Francis Young's Magic as a Political Crime in Medieval and Early Modern England makes an important contribution to both the historiography of political culture in medieval and early modern England and the historiography of magic. This book develops ideas from Young's previous monograph English Catholics and the Supernatural, 1553-1829. The chronological range of the study is the 14th century to the late 1690s and focuses exclusively on England, although there are a few mentions of Scottish developments for comparison and a section analysing the Affair of the Poisons in France. It builds on Glyn Parry's biography of John Dee and his investigation of Dee's role in combatting magical plots against Elizabeth I and Peter G. Maxwell Stuart's assertion that magical treason should not be consigned to the margins of historiographical investigations of this period. Young's study is distinctive in his focus on magic rather than witchcraft in this period. By shifting the historical lens from witchcraft to consider wider allegations Young highlights how the use of magic was an accusation which could befall lay and elite women and men alike. The legal development of magic as a political crime has been previously neglected because historians have often approached witchcraft as a social phenomenon. This has resulted in an important facet of medieval and early modern political life being ignored. Across different regimes various privy councillors, courtiers and monarchs were concerned that magic would be employed for seditious purposes. Young underscores how anxiety surrounding the possibility of magical treason was an important part of the medieval and early modern political landscape. Magic expanded from the ordinary and commonplace business of daily life to challenging political rule as the claims of the central government extended further. Young plots how magic and treason intertwined as church courts and the monarch's laws both claimed jurisdiction. Legislation surrounding magic thus provides a useful insight into conflicts of power between Church and State. Magical treason is an effective way to explore medieval and early modern political culture. Anxiety, or lack of anxiety, surrounding magical treason exposed a ruler's self-perception. The high-points of magical treason allegations emphasise an understanding of one's own vulnerability; as Young argues, a ruler was as vulnerable as anyone else to magic as walls and palaces couldn't protect more than a humble stone home. A lack of concern about magical plots reveals a ruler's conception of themselves as divinely chosen and 
protected.

Young's use of occult Latin texts enables him to reconstruct the possible content of the magical practices of which people were accused. It shows the learning needed to undertake these magical activities. This underlines the distinction between magic and witchcraft as a category and gives a flavour of the type of people who were open to accusations of magical sedition. The allegation of magical treason targeted the powerful whereas witchcraft was usually used against those who were politically disempowered. Young addresses the limitations of the sources by setting individual accusations of magical treason in the context of known possible magical practices. He successfully shows the inheritance of ideas about magic and questions the plausibility or implausibility that these magical plots could occur. These manuscripts are considered alongside records of parliamentary debate, the wording of legislation, and state records of trials which show the impact these allegations had on the wider political context. A careful consideration of magic and witchcraft in Shakespeare's works gives some indication of the broader reception and understanding of magical crime. Young's work opens up a realm of possibilities and firmly fixes the importance of magic as a distinct category from witchcraft.

Chronologically ordered, the monograph begins with a consideration of the emergence of magic as a political crime in the 14th century. It assesses the first unequivocal case of an individual being accused of attempting to employ magic to commit treason. The case of John of Nottingham and the plot against Edward II supports Young's argument that magical sedition often emerged as a challenge to a monarch overextending their rights. In this case it was the result of a taxation dispute. Young's analysis of the Liber imaginum manuscript brings to life 15th-century practices and makes a convincing case that these would have been similar to the practices of which John of Nottingham was accused. This method of reconstruction means that Young does not just say image magic or effigy magic but explains the process and rituals involved. Young then considers the role of magic in the Statute of Treason 1351 and the tensions between Church and State regarding the punishment of magicians. It traces how the change in jurisdiction from Church to State in punishing magic brought astrology into disrepute and altered what was considered acceptable academic pursuits. The argument that it was the State rather than the Church which made magic more dangerous is convincing.

Chapter two explores treason, sorcery and prophecy in the early Reformation from Henry VIII to the death of Mary I. This chapter examines how the Tudors further enlarged what came under the government's remit and thus what could be considered a political crime. It evaluates how prophecy and magic became closely connected and the impact of this upon allegations of treason. Young makes the astute observation that although the 1542 act made any form of magic a felony,

historians have tended to treat the act of 1542 as a forerunner to the better known "Witchcraft Acts" of 1563 and 1604, but this glosses over the fact that no one accused of the crime of witchcraft... was ever tried under the 1542 statute (p. 77).

Young shows how the emphasis of the 1542 legislation was on magical treasure hunting and legislating the notion that contempt for the king's property was akin to contempt for his person. Young explores how the definition of magic changed in Edward VI's reign and how government interest in treasonable magic waned under Mary I. This chapter reveals how magic both acquired and lost its potency depending on the government's fears and interests. The flux in anxiety surrounding treasonable magic ran parallel to religious changes and the development of the Reformation in England. Young closes this chapter by showing how, while still under house arrest, Elizabeth turned to John Dee in an attempt to gain some clarity over what the future may hold.

Young examines treasonable magic in the reign of Elizabeth I in the following two chapters. The structure of Young's text emphasises that this was the crescendo of early modern treasonable magic. Young's discussion of the fact that Elizabeth had utilised magic during her captivity re-enforces his underlying argument that the importance and frequency of treasonous magic relied upon how those supposedly under attack viewed 
magic. Elizabeth's own perceptions of the potential power of magic was significant because 'Elizabeth I was perhaps the most magically attacked monarch - at least while on the throne of England - in English History' (p. 87). Beginning with a consideration of Elizabeth versus the Popish Conjurers of 1558-77, Young highlights the insecurities of Elizabeth's reign due, in a large part, to Elizabeth's refusal to marry. He argues that power in the Elizabethan period was centralised and the government extended what it considered to come under its jurisdiction. This chapter supports the contention running throughout this monograph that an increase in magical treason was tied to the transfer from Church to State of the power to prosecute this crime. Young makes a significant contribution to the historiography of witchcraft in his reconsideration of the 1563 Act Against Conjuration and Witchcraft. Through a reconstruction of the immediate background to the bill and a clarification of the important distinction which early modern people made between magic and witchcraft Young exposes the difference between how the bill was worded and likely intended to work and how it was applied. Young makes the convincing argument that the parameters of the 1563 'Witchcraft Act' were altered with its use in the 1566 Chelmsford Witch trial. After being deployed against mostly female 'witches' a legal precedent was set for interpretation outside of the bill's original drafting which depoliticised the act as it directed the attention of magistrates to the socially marginalised rather than couturiers and clergy.

An alternative understanding of contemporary events is introduced through consideration of how the Catholic leader Robert Parsons blamed the misfortunes which befell Elizabeth's government on God's providence rather than Catholic magic. This reader would have liked the differences between Protestant and Catholic perceptions of magic to be explored further. Was this blaming of misfortune on God's providence representative of a less magical worldview or just a means to exonerate fellow Catholics from claims of wrongdoing? Did Catholics and Protestants share similar beliefs of the capability of magic? This highlights an opportunity for future work to investigate Catholic providentialism and balance previous historiography which has focused on this strain of Protestant thought. Was magical treason a projected Protestant fear or did Catholics in general view it as a viable option? Young shows in response to the burning of St Pauls on 4 June 1561 that accusations of magic coloured Reformation debates and positions Catholics as more providential in their outlook than their Protestant neighbours. While describing the Catholic priest John Morwen's pamphlet in the aftermath of the burning this reader would have appreciated comment on whether this was rhetoric and propaganda or reflective of a more providential worldview. That Catholics interpreted the event providentially is supported by Robert Parsons's anger, still being expressed 20 years later, that the burning of St. Paul's was attributed to Catholic magic rather than providence. This evidence suggests that Catholic providentialism is a topic that needs exploring.

Chapter four discusses the incidents of 1578- 9 of suspected effigy magic against Elizabeth I and the witchhunts of 1578-1603. While Young is clear that the exact counter magic which John Dee used to naturalise the supposed threat of these effigies is not recorded, his conjectures as to the possible type of counter-magic employed by Dee are well reasoned and supported by a firm and broad understanding of early modern beliefs about the potential of magic. With regards to the witch hunt of 1579 led by the earl of Leicester against English Catholics Young emphasises how important the wider context was for legal developments and fear of both magical crime and witchcraft. Although it is made clear in the introduction that Young regards prophecy as inconsequential after the 1560s a fuller explanation of this viewpoint would have been beneficial at this point (p. 7). Prophecy is a theme which runs throughout this book but without comment; nor are the links between prophecy and magic investigated. Young argues that 'in the 1560s magic was closely associated with prophecy' but does not support his contention that this link was severed in the 1570s (p. 109). The monograph examines the Vincent Murphyn conspiracy and details how Murphyn claimed that in 1579 Sir George Hastings produced some prophecies which related to the crowning of Mary Queen of Scots (p. 139). Vincent Murphyn arguably personifies the link between suspected magic, suspected sedition and suspected prophecies. Young's dismissal of prophecy as inconsequential after the 1560s may be questioned: the vibrancy of early modern English Catholic eschatology challenges this contention. The possible links between magic and prophecy may be a fruitful area for future study. 
chapter contends that despite the fact that James brought a heightened fear of magical treason, James feared witchcraft less than any other monarch. Young shows how James's diminished fear of magic rested on his notion of kingship rather than a disbelief in the reality and power of magic. James perceived himself as God's anointed and believed that he was subsequently directly protected by God from magical harm. This chapter supports the argument that studying magic as a political crime reveals alterations in political power, jurisdiction and ideas about monarchy. The magical treason scandal of the 1620s showed how public opinion was aligned against the Duke of Buckingham and implicitly King Charles I. Young's argument that this was a sign that the centralised systems of government established by Henry VIII and Elizabeth I were beginning to unravel is persuasive (p. 173). The accusations of magical treason were attacks on the court from the outside 'in contrast to the Tudor period when accusations of magical treason often emanated from - or were encouraged by - the monarch's own ministers' (p. 173). This highlights a shift in public opinion as allegations of magical treason demonstrate who was perceived to be the enemy of the nation.

The final chapter considers the decline of magic as a political crime across the period from the English Civil Wars to the 1690s. Young argues that 'old anxieties about magical threats to government emerged most obviously on the parliamentarian side' (p. 180). The monograph traces a link between the accusations in the era of the English Civil Wars to how Archbishop Laud was frequently alleged to practice necromancy. Magic as a political crime is presented as a tradition which continued and magic as a threat appeared to expand. The interruption of law and order and instability of the time appears to have made English people more resolute to denunciate and punish wrongdoers. The chastisement of those accused of magic seems to have been a means of policing boundaries during a period when regulations and understandings of what was natural would often be in flux. The relatively rapid diminishing of magic as a political crime in England during the Interregnum and Restoration is contrasted with its persistence in other European nations such as France. The loosening of censorship of print meant that magic lost much of its mystique. The rhetoric of pamphlets against witchcraft, treason and magic did not translate into judicial enthusiasm for prosecuting those accused. However, Young shows that English actors had a large role to play in the scandal of magical treason which erupted in France in 1676 suggesting that belief in the viability of magic as a weapon did not wane as quickly as English court records suggest. Nevertheless, by the 1690s the association of treason with magic was the subject of satire. A separate conclusion rather than a sub-section of the last chapter would have been helpful. This work is wide-ranging in terms of the period it covers and provides compelling arguments concerning the need to distinguish between magic and witchcraft in historical analysis.

The author thanks Dr Casey-Stoakes for her thorough and balanced review.

Source URL:https://reviews.history.ac.uk/review/2219

\section{Links}

[1] https://reviews.history.ac.uk/item/294789 